\title{
Literasi Digital dalam Upaya Mendukung Pembelajaran Online pada Siswa Sekolah Dasar di Kota Cilegon
}

\author{
Siska Mardiana ${ }^{1}$, Annisarizki ${ }^{2}$, Marthalena ${ }^{3}$, Liza Diniarizky Putri ${ }^{4}$, Sigit Surahman ${ }^{5}$ \\ 1234Prodi Ilmu Komunikasi Universitas Serang Raya \\ 5Prodi Ilmu Komunikasi Universitas Bhayangkara Jakarta Raya \\ Email : ${ }^{1}$ mardiana.siska@yahoo.com, ${ }^{2}$ annisarizzkii@gmail.com, \\ 3marthalena.marthalena@gmail.com, 4 i_jupri@rocketmail.com, ${ }^{5}$ saleseven@gmail.com
}

\begin{abstract}
Abstrak
Pembelajaran online yang dilakukan melalui media sosial ataupun aplikasi conference yang ada di smartphone atau komputer, pada akhirnya membuat siswa-siswa pun banyak menggunakan teknologi digital, atau ada juga yang memang sudah terbiasa menggunakannya sebelum adanya pembelajaran online, demikian yang dialami oleh siswa-siswa di SDIT Madani Cilegon, maka kegiatan pengabdian masyarakat mengenai literasi digital dilakukan dengan tujuan memberikan pengetahuan mengenai bagaimana mengakses internet dengan baik, aman dan sehat, aplikasi apa saja yang baik untuk mereka gunakan dan penggunaan smartphone yang baik dan bijak. Kegiatan dilakukan selama tiga bulan mulai dari tahap awal sosialisasi dan perijinan hingga tahap evaluasi. Hasil kegiatan pengabdian ini menunjukkan bahwa siswa lebih memahami mengenai penggunaan internet dan teknologi digital seperti smartphone untuk hal hal yang positif, juga mengenai keamanan di dunia digital, dan pencarian sumber informasi dan konten konten yang sesuai dengan usia. Keberhasilan kegiatan ini ditunjukkan dengan antusiasme siswa mengikuti kegiatan dan peserta mampu menjawab pertanyaan, mengulang menjelaskan materi serta dari informasi yang didapat dari guru usai kegiatan dah hasil evaluasi menunjukan $91 \%$ peserta memahami bagaimana mencari informasi untuk pembelajaran. Kegiatan pengabdian ini juga mendorong keberhasilan pembelajaran online karena siswa dapat mencari informasi, membaca, menyimak, melalui media digital seperti blog, media sosial, web maupun youtube, dan dapat mengikuti pembelajaran tiap mata pelajaran yang berlangsung secara online.
\end{abstract}

Kata Kunci : Literasi Digital, Pembelajaran Online, Internet.

Abstract

Online learning that is carried out through social media or conference applications on smartphones or computers, ultimately makes students use digital technology a lot, or some are already accustomed to using it before online learning, as experienced by students at SDIT Madani Cilegon, community service activities regarding digital literacy are carried out with the aim of providing knowledge about how to access the internet properly, safely and healthily, what applications are good for them to use and good and wise use of smartphones. The activity was carried out for three months starting from the initial stage of socialization and licensing to the evaluation stage. The results of this service activity show that students understand better about using the internet and digital technology such as smartphones for positive things, also about security in the digital world, and finding sources of information and ageappropriate content. The success of this activity was shown by the enthusiasm of students in participating in the activity and answering questions, repeating explaining the material and from the information obtained from the teacher after the activity. This service activity also encourages the success of online learning because students can search for information, read, listen, through digital media such as blogs, social media, web and YouTube, and can follow the learning of each subject that takes place online.

Keyword: Digital Literacy, Online Learning, Internet. 


\section{PENDAHULUAN}

Pembelajaran Online menjadi pembelajaran yang harus dilakukan pada masa pandemi Covid-19 karena adanya protokol kesehatan yang harus dijalani seperti menjaga jarak, sehingga siswa melakukan pembelajaran dari rumah secara online (Garini, Respati, \& Mulyadiprana, 2020)(Sari, Tusyantari, \& Suswandari, 2021). Pembelajaran secara online dilakukan dengan menggunakan berbagai aplikasi seperti zoom, google meet, ataupun melalui media sosial seperti Whatsapp dengan dukungan adanya jaringan internet dan perangkat seperti Smartphone (Sulastri, Maula, \& Uswatun, 2020)(Mardiana, 2020).

Penggunaan internet ini sejalan dengan penggunaannya di dunia yang terus meningkat, berdasarkan hasil survey pada Januari 2021 dari total populasi 7.83 billion jiwa, sebanyak $66.6 \%$ atau 5.22 billion jiwa menggunakan smartphone, kemudian 59.5\% atau sebanyak 4.66 billion menggunakan internet dan sebanyak 4.20 billion atau $53.6 \%$ sebagai pengguna aktif media sosial (https://wearesocial.com/digital-2021).

Sementara untuk di Indonesia, pada Januari 2021 dari total populasi penduduk 274.9 million, sebesar $73.7 \%$ atau 202.6 million adalah pengguna internet. Hal ini menunjukkan peningkatan penggunaan internet dari tahun sebelumnya yaitu sebesar $15.5 \%$ yaitu 27 juta jiwa. (https://datareportal.com/reports/digital2021-indonesia).

Akan tetapi, pertumbuhan penggunaan internet yang besar di Indonesia ini tidak dibarengi dengan peningkatan kemampuan literasi digital (Yustika \&
Iswati, 2020)(Ahsani, 2021). Definisi literasi digital di sini tidak hanya menyangkut kemampuan menggunakan teknologi, seperti keterampilan untuk menggunakan perangkat lunak, dan internet dasar. Akan tetapi, termasuk keterampilan literasi digital seputar kemampuan untuk memahami, mengevaluasi, dan menggunakan informasi yang didapat dari sumber digital dengan penuh tanggung jawab yang menjadi fokus utama dari ringkasan kebijakan ini (https://id.cips-

indonesia.org/post/memajukan-

keterampilan-literasi-digital-siswa-melaluipemutakhiran-kurikulum-sekolah). Gilster mengemukakan literasi digital sebagai kemampuan untuk memahami dan menggunakan informasi dalam berbagai format dari beragam sumber digital (Aziz, Syam'aeni, Sya'baniyah, \& Fatihah, 2020).

Pengabdian mengenai literasi digital pernah dilakukan di SDN Tanjakan Kabupaten Tangerang dnegan indikator keberhasilan kegiatan terjadi peningkatan pemahaman mengenai literasi digital yang ditunjukkan oleh pemahaman siswa mengetahui mana informasi yang benar dan salah, mampu membuat password yang kuat dan dapat berkomunikasi positif di dunia digital (Aziz et al., 2020). Kegiatan Literasi digital selanjutnya dilakukan di Sekolah Dasar Indonesia DenHaag yang menggunakan sumber sumber pembelajaran berasal dari youtube (Ahsani, 2021).

Literasi digital mengenai penggunaan internet dan smartphone seharusnya dapat menjadi support dalam pelaksanaan pembelajaran dari rumah secara online terutama di masa pandemi 
Covid ini, pembelajaran online yang dilakukan melalui media sosial ataupun aplikasi conference yang ada di smartphone atau komputer, pada akhirnya membuat anak anakpun terpaksa dikenalkan dengan smartphone, atau ada juga yang memang sudah terbiasa menggunakannya sebelum adanya pembelajaran dari rumah, demikian juga dialami oleh siswa siswa di sebuah sekolah dasar di Kota Cilegon.

Penggunaan smartphone pada usia siswa Sekolah Dasar ini sangat membutuhkan pendampingan dan perhatian yang lebih baik dari orang tua, namun terkadang karena kesibukannya orang tua pun lalai dan membiarkan anak menggunakan smartphone sendiri. Selain itu juga adanya keluhan dari pihak guru yang merasa bingung karena dihadapkan dengan dilema harus memberikan materi dengan jarak jauh, namun jadi mengakibatkan anak anak banyak menggunakan smartphone untuk bermain, dan belum banyaknya sosialisasi mengenai penggunaan internet dan smartphone bagi siswa Sekolah Dasar yang aman dan sehat.

Berdasarkan berbagai permasalahan tersebut , maka kegiatan pengabdian masyarakat ini dilakukan dengan tujuan memberikan pengetahuan mengenai bagaimana menggunakan smartphone, mengakses internet dengan baik, aman dan sehat, aplikasi apa saja yang baik untuk mereka gunakan dan sebagainya, dengan harapan mereka dapat menggunakannya dengan bijak, walaupun tetap saja akan dibutuhkan peran orang tua untuk mendampingi penggunaannya, sehingga media digital yang digunakan dapat mendukung pembelajaran online.

\section{METODE PELAKSANAAN}

Metode pelaksanaan kegiatan menjelaskan tahapan atau langkah-langkah yang dilakukan dalam melaksanakan solusi yang ditawarkan untuk mengatasi permasalahan, yang terdiri dari tahap awal, tahap persiapan, tahap pelaksanaan dan tahap evaluasi. Pada tahap persiapan, kegiatan dimulai dengan analisis situasi terkait dengan masalah yang ingin diatasi, menentukan calon peserta, untuk mengeksplorasi permasalahan yang dihadapi. Kegiatan ini menggunakan metode Problem Based Learning yaitu memberikan pembelajaran kepada siswa terkait permasalahan yang dihadapi yaitu literasi digital dalam upaya mendukung pembelajaran online. Selain itu pelaksanaan kegiatan menggunakan metode diskusi, simulasi permainan, dan tanya jawab. Selanjutnya proses alur kegiatan pengabdian digambarkan sebagai berikut:

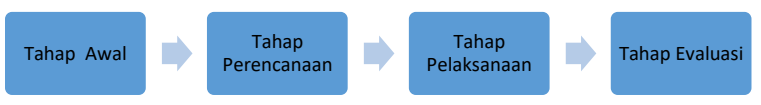

Gambar 1. Proses Kegiatan Pengabdian

Untuk lokasi pengabdian dilakukan di sebuah sekolah Islam Terpadu di Kota Cilegon yaitu di SDIT Madani Cilegon. Jadwal kegiatan pengabdian masyarakat dimulai dari bulan April hingga Juni 2021, adapun jadwal kegiatan disajikan pada tabel berikut :

Tabel 1. Jadwal Kegiatan Pelaksanaan

\begin{tabular}{ccccc}
\hline No & Jenis & April & Mei & Juni \\
& Kegiatan & 2021 & 2021 & 2021 \\
\hline
\end{tabular}




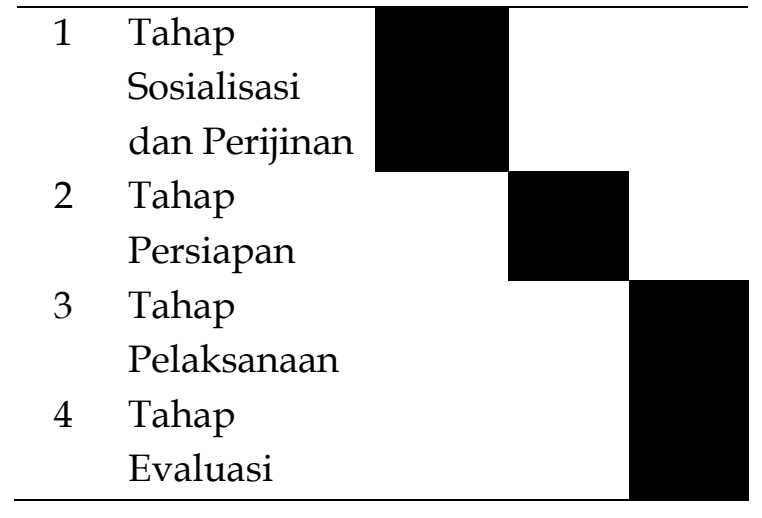

\section{HASIL DAN PEMBAHASAN}

Kegiatan pengabdian dilakukan di SDIT MADANI Kota Cilegon selama tiga bulan mulai dari bulan April hingga Bulan Juni 2021. Pada tahap awal kegiatan, ada dua agenda utama yang dilakukan yaitu observasi dan wawancara. Kegiatan observasi dan wawancara dilakukan dengan berkunjung ke Sekolah untuk meminta ijin kepada Kepala Sekolah juga Wali Kelas, kemudian menemui guru guru dan beberapa orang tua siswa yang saat itu beberapa sedang berada di sekolah. Dari hasil wawancara awal, guru guru menceritakan keluhan orang tua wali mengenai kekhawatiran mereka akan dampak negatif dari smartphone, karena pembelajaran daring memaksa mereka memberikan akses penggunaan yang lebih banyak kepada anak anaknya, dan hal ini di iyakan oleh orang tua. Anak anak mereka banyak yang menghabiskan waktu bermain game di smartphone saat dirumah, termasuk di sela sela waktu belajar online, seperti pada saat sedang menunggu jadwal mata pelajaran selanjutnya.

Selanjutnya berdasarkan informasi yang didapat melalui wawancara dan observasi awal, kami melanjutkan pada tahap selanjutnya yaitu tahap persiapan. Pada tahap ini, tim kami mempersiapkan materi, alat dan bahan yang dibutuhkan. Untuk kegiatan pengabdian Literasi Digital bagi Siswa SDIT Madani, tim membuat semacam brosur dengan ukuran besar dan dibuat dengan warna warni ceria dan penggunaan Bahasa yang mudah dipahami oleh target sasaran yaitu siswa Sekolah Dasar. Brosur ini berisikan materi mengenai penggunaan internet dan smartphone yang baik bagi siswa. Brosur dicetak sesuai dengan jumlah peserta kegiatan karena dibagikan kepada seluruh siswa yang mengikuti kegiatan. Selain itu tim juga menyediakan, beberapa pamflet berisikan informasi informasi mengenai pemakaian internet yang sehat bagi siswa Sekolah Dasar dan kuesioner untuk mengetahui pengetahuan siswa mengenai penggunaan internet dan smartphone yang baik, sebelum dan sesudah kegiatan, untuk dijadikan bahan evaluasi.

Kemudian di bulan Juni 2021, tim pengabdian melakukan tahap pelaksanaan pengabdian yang melibatkan siswa dan guru kelas pada Kelas 4. Kegiatan berlangsung secara tatap muka dengan protokol kesehatan yang ketat sesuai aturan pemerintah, karena saat itu Kota Cilegon berada pada level zona kuning, sehingga dibolehkan melakukan kegiatan pembelajaran tatap muka secara terbatas, kegiatan dilakukan pada hari terakhir siswa melaksanakan PAS secara tatap muka di lingkungan sekolah, hal ini bertujuan supaya kegiatan pengabdian tidak mengganggu aktivitas utama siswa dan guru.

Pelaksanakan diawali dengan membagikan kuesioner yang berisikan beberapa pertanyaan mengenai bagaimana 
mereka menggunakan smartphone dan internet, juga pemahaman mereka mengenai beberapa hal seperti batasan waktu yang baik menggunakan smartphone, informasi dan hoaks, keamanan digital dan memilih konten yang sesuai usia. Kuesioner diisi bersama, dengan dibacakan oleh tim pengabdian dan mereka mengisi dibantu dengan tim dan beberapa guru kelas saat itu. Selanjutnya kuesioner dikumpulkan, dan dibagikan kertas berisikan materi mengenai literasi digital. Pada sesi ini tim pengabdian menjelaskan materi dengan metode diskusi dan menyelipkan permainan permainan bagi siswa sehingga suasana menjadi hidup dan mereka terlihat senang dan memahami yang disampaikan. Metode permainan membuat siswa menjadi lebih santai, interaktif dan kreatif (Dina Salsabella Utami, 2021).

Materi yang disampaikan diantaranya mengenai batasan waktu yang baik menggunakan smartphone, juga jarak yang baik sekitar $40-50 \mathrm{~cm}$ antara smartphone dengan penglihatan, karena kita juga harus menjaga kesehatan mata. Selain itu juga disampaikan kepada peserta mengenai pentingnya menjaga privasi atau data pribadi di ruang digital, demi keamanan dan kenyamanan keluarga, serta hal lain seperti memilih aplikasi atau game yang sesuai dengan usia, dan selalu terbuka menceritakan dan berdiksusi dengan orang tua mengenai aktivitas di ruang digital yang dilakukan, sehingga internet dan smartphone dapat digunakan untuk hal yang baik. Semua peserta begitu antusias selama mengikuti kegiatan ini, nampak dari beberapa murid-murid yang begitu semangat selama mengikuti kegiatan ini. Untuk lebih memperjelas dapat dilihat pada gambar-gambar dokumentasi kegiatan berikut :

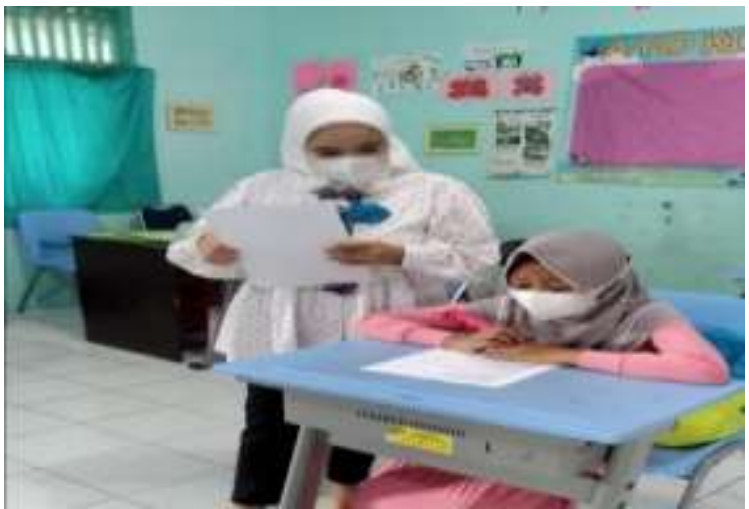

Gambar 2. Tim Pengabdian mendampingi pengisian kuesioner

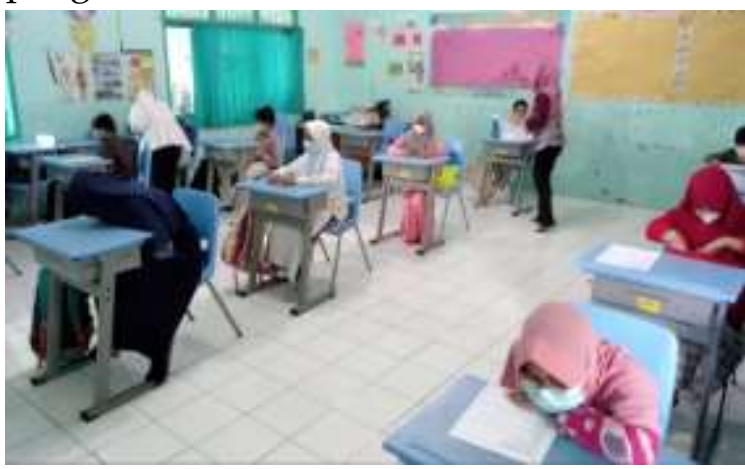

Gambar 3. Tim pengabdian melakukan interaksi kepada peserta

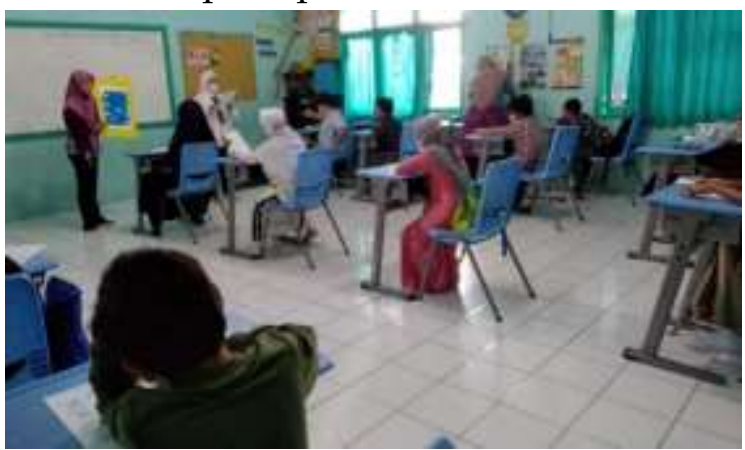

Gambar 4. Tim pengabdian menyampaikan materi literasi digital

Tahap selanjutnya adalah tahap evaluasi, yaitu untuk mengetahui apakah materi yang disampaikan dapat diterima dengan baik juga memberikan pengetahuan mengenai literasi digital sehingga mereka 
dapat menggunakan internet sehat dan smartphone dengan lebih bijak. Tahap ini dilakukan dengan mengajukan beberapa pertanyaan kepada beberapa peserta dan meminta seluruh peserta untuk menjelaskan ulang apa yang sudah disampaikan. Hasilnya adalah hampir seluruh peserta dapat mengerti materi yang disampaikan dengan baik. Hasil ini juga dibandingkan dengan hasil kuesioner yang diisi pada awal kegiatan bahwa masih ada siswa yang belum memahami mengenai penggunaan internet dan smartphone yang sehat dan bijak, seperti yang disajikan pada gambar berikut:

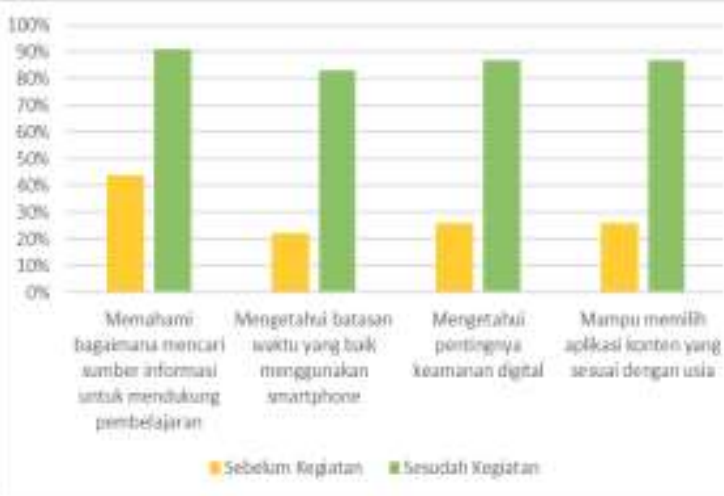

Gambar 5. Tanggapan peserta mengenai materi yang disampaikan

Selain itu, tahap evaluasi juga dilakukan sesudah kegiatan dengan meminta informasi dari wali kelas bagaimana tanggapan sesudah pelaksanaan kegiatan, dan guru menyampaikan bahwa siswa menjadi lebih mengerti bahwa harus menjaga data privasi di dunia digital, harus menjaga batasan waktu penggunaan smartphone juga lebih berhati hati memilih sumber informasi di internet.

Penggunaan internet dan media digital seperti smartphone saat ini tidak dapat dihindari oleh siswa Sekolah Dasar, karena mereka juga termasuk dalam digital native yaitu anak anak yang memang lahir dan hidup di tengah perkembangan digital (Mar'ah, Rusilowati, \& Sumarni, 2020). Internet pada beberapa anak digunakan untuk bermain game online (Syarifuddin, 2015)(Mardiana, 2019), namun diperlukan upaya sehingga penggunaan internet sehat dan media digital ini untuk hal hal yang positif, salah satunya dengan penguatan literasi digital(Yustika \& Iswati, 2020). Sebagian besar siswa sudah mengenal internet, namun belum faham mengenai kejahatan yang dapat terjadi di ruang digital(Syuhardi, 2019). Penguatan literasi digital dapat mendorong kegiatan pembelajaran yang dilakukan secara online berjalan lebih baik, karena siswa dapat memilah informasi melalui media digital seperti media sosial, blog, web dan youtube (Afiandi, 2002) dan memilah informasi yang dibutuhkan terkait proses pembelajaran berbasis e-learning(Wijayanti, Degeng, \& Sitompul, 2021).

\section{KESIMPULAN DAN SARAN}

Kegiatan pengabdian mengenai literasi digital pada siswa di SDIT Madani Cilegon, telah memberikan penguatan kepada siswa mengenai penggunaan internet dan media digital untuk hal hal yang positif, siswa lebih memahami mengenai keamanan di dunia digital, dan pencarian sumber informasi dan konten konten yang sesuai dengan usia. Kegiatan pengabdian ini juga mendorong keberhasilan pembelajaran secara daring karena berdasarkan hasil evaluasi sebesar 91\% siswa dapat mencari informasi, membaca, menyimak, melalui media digital seperti blog, media sosial, web maupun youtube, dan yang utama dapat mengikuti pembelajaran yang berlangsung 
secara online, sehingga walaupun di masa pandemi Covid, pembelajaran dapat berlangsung dengan baik. Selanjutnya saran untuk kegiatan pengabdian selanjutnya mengenai literasi digital bagi siswa Sekolah Dasar dapat dilakukan juga di sekolah sekolah lain, atau juga untuk siswa tingkat SLTP dan SLTA tentu saja dengan pemberian materi dan metode pelaksanaan yang menyesuaikan dengan kebutuhan di lokasi tersebut

\section{DAFTAR PUSTAKA}

Afiandi, W. (2002). Perilaku pengakses dan pemanfaatan intenet dalam kegiatan akademik di kalangan siswa sd. Journal Kegiatan Akademik, (1). Retrieved from http://journal.unair.ac.id/downloadfullpapers-palim276ac3428f2full.pdf

Ahsani, et al. (2021). Penguatan Literasi Digital dalam Pembelajaran di Sekolah Dasar Indonesia Den Haag. Elemantary School, 8(2), 228-236.

Aziz, R. M., Syam'aeni, M. A., Sya'baniyah, N., \& Fatihah, I. C. (2020). Peningkatan Kemampuan Literasi Digital bagi Siswa Kelas 4 dan 5 SDN Tanjakan 3, Kabupaten Tangerang. Jurnal Pengabdian Pada Masyarakat, 5(1), 141148.

https:// doi.org/10.30653/002.202051.2 67

Dina Salsabella Utami, A. T. A. H. (2021). Pengembangan Media Belajar Literasi Digital Berbasis Game Edukasi Dalam Meningkatkan Minat Baca Kelas 2 SD. JIKAP PGSD: Jurnal Ilmiah Ilmu Kependidikan, 5(2), 218-225.

Garini, A. W., Respati, R., \& Mulyadiprana, A. (2020). Penggunaan Media berupa Digital pada Masa Pandemi di Sekolah Dasar. Pedidaktika Jurnal Ilmiah Pendidikan Guru Sekolah Dasar, 7(4), 186191.

Mar'ah, N. K., Rusilowati, A., \& Sumarni, W.
(2020). Perubahan Proses Pembelajaran Daring Pada Siswa Sekolah Dasar. Prosiding Seminar Nasional Pascasarjana UNNES, 446.

Mardiana, S. et al. (2019). Measuring Digital Literacy for Students With Visual Impairments. Library Philosophy and Practice DigitalCommons @ University of Nebraska - Lincoln, 43(12), 2-14.

Mardiana, S. et al. (2020). Communication Technology for Student With Visual Impairments: A Case Study of Smartphone. Advances in Social Science, Education and Humanities Research, 459(Jcc), 53-56.

Sari, R. P., Tusyantari, N. B., \& Suswandari, M. (2021). Dampak Pembelajaran Daring Bagi Siswa Sekolah Dasar Selama Covid-19. Prima Magistra: Jurnal Ilmiah Kependidikan, 2(1), 9-15. https://doi.org/10.37478/jpm.v2i1.732

Sulastri, D., Maula, L. H., \& Uswatun, D. A. (2020). Pemanfaatan Platform Digital dalam Pembelajaran Daring di masa Pandemi Covid-19. Prosiding Seminar Nasional Pascasarjana UNNES, 910-914, 910-914.

Syarifuddin. (2015). Motif Penggunaan Teknologi Informasi Dan Motif Use of Information and Communication. Jurnal Penelitian Komunikasi Dan Opini Publik, 19(1), 43-55.

Syuhardi, Y. I. (2019). Pengenalan dan Pemanfaatan Internet Sehat. Jurnal Pendidikan Dasar Perkhasa, 5(2), 116-120.

Wijayanti, H., Degeng, I. N., \& Sitompul, N. (2021). Pengembangan Bahan Ajar Berbasis E-Learning Pada Pembelajaran Tematik Sekolah Dasar. Edcomtech Jurnal Kajian Teknologi Pendidikan, 6(1), 26-35.

https://doi.org/10.17977/um039v6i12 $021 \mathrm{p} 026$

Yustika, G. P., \& Iswati, S. (2020). Digital Literacy in Formal Online Education: A Short Review. Dinamika Pendidikan, 15(1), 66-76. 
https:// doi.org/10.15294/dp.v15i1.237 79

https://wearesocial.com/digital-2021 https://datareportal.com/reports/digital2021-indonesia https://id.cipsindonesia.org/post/memajukanketerampilan-literasi-digital-siswa-melaluipemutakhiran-kurikulum-sekolah 